\title{
Physical Activities and Construct of Health Belief Models in the Special Region of Yogyakarta in the Era of Pandemy Covid-19
}

\author{
Arika Umi Zar'in', Novita Intan Arovah ${ }^{2}$ \\ ${ }^{1,2}$ Sport Science Study Program, Universitas Negeri Yogyakarta, Indonesia
}

\section{Abstract}

This study aims to determine (1) the pattern, level and status of physical activity, (2) differences in the level of physical activity based on the construct status of the health belief model and (3) the relationship between physical activity status and the construct status of the health belief model in the people of the Special Region of Yogyakarta. This research is a cross-sectional observational survey research on the DIY community as many as 390 people using convenience sampling technique with online questionnaire. Physical activity is measured using the Global Physical activity Questionnaire (GPAQ) which calculates the metabolic equivalent of task (MetS) per week, while the health belief model construct is measured using the adaptation instrument from the COVID-19 snapshoot and monitoring (COSMO-WHO). The pattern of physical activity is seen by the level of physical activity in three domains (work, transport and leisure or recreation). The difference in the level of total physical activity in the construct of health belief model uses kruskall-wallis, while the relationship between physical activity status and constructs in health belief is tested by using chi square with a confidence level of 5\%. The results of this study indicate that the physical activity pattern of the DIY community is dominated by recreational activities, with an average of 868.37 Mets /week, followed by the work domain with an average of 521.28 Mets / week and the transport domain with an average of 233.54 Mets / week. People who fall into the category of moderate physical activity status are $71 \%$. DIY people who have a high level of HBM status tend to have sufficient physical activity status with a sig value of 0,000 in all constructs. It can be concluded that there is a relationship between the HBM construct and the physical activity status in the new normal era in the DIY community with high HBM status, so they will have a better level of physical activity status than those who have low HBM status, with a correlation value of 0.89 which meaning very strong.
Keywords

physical activity, covid-19; health belief model

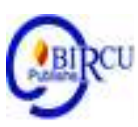

\section{Introduction}

Corona virus $(\mathrm{CoV})$ is a large family of viruses that can infect animals, mammals and humans (Zendrato, 2020). The spread (CoV) has claimed many victims in a short time so that the world health agency WHO raised its status to a global pandemic and named this virus as COVID-19. a disease that mainly attacks the respiratory tract and can spread from person to person who has been infected with the virus. This transmission also occurs through the surrounding environment, one of the transmissions occurs when handling objects that have been contaminated with droplets from people with COVID-19.(Morawska \& Cao, 2020). In 
an effort to break the chain of transmission of COVID-19, the Indonesian government recommends prevention that can be done through diligently washing hands, wearing masks, maintaining distance, avoiding crowds, not traveling long distances and reducing the use of public transportation. Prevention can also be done by you by increasing the body's immunity by consuming balanced nutrition, adequate rest, consuming vitamins and doing physical activity (Fauziyati, 2017). So that the response to the COVID-19 outbreak can be handled quickly, the government issued a policy on health quarantine which includes home quarantine, hospital quarantine, regional quarantine and large-scale social boundaries (PSBB). Following the latest developments, the government then relaxed the PSBB policy known as the New Normal Era (adaptation of new habits). The community is faced with new habits that have not previously been carried out, the government will begin to implement these new habits as an effort to make the community return productive but still safe from COVID-19 by implementing health protocols. The current conditions made physical activity or sporting activity as difficult as it was before the pandemic. On the other hand, the need for efforts to increase immunity in the Covid era has also increased the awareness of several groups of people to increase their physical activity. So far, it is not known the impact of social restrictions during the pandemic on the pattern, level and status of physical activity of the Yogyakarta community. Apart from not knowing what factors are related to physical activity behavior in the DIY community. In this case, the World Health Organization has provided guidelines in conducting surveys (WHO Tool for Behavioral Insights on COVID19, 2020) which can be adapted for the benefit of surveys related to COVID-19 in the community. This instrument is based on the theory of behavior change (behavior change), especially the Health Belief model.

\section{Research Methods}

This study used an observational cross-sectional study. Research that takes measurements at one time, which measures the pattern, level and status of physical activity and the relationship with the construct of the health belief model in the people of the Special Region of Yogyakarta start from August-September 2020. Research Sample is 390 respondents. The populations in this study were all of the people of the Special Region of Yogyakarta. The samples in this study used convenience sampling. The population criterion in this study was the community who filled out a questionnaire on an online form that had been distributed through a digital platform. The determination of the number of samples is determined by the proportion estimation formula. Researchers assume that using a confidence level of $95 \%$ so that the sample size required is 390 people. The population in this study is the people of the Special Region of Yogyakarta who have filled out a questionnaire that has been distributed through digital platforms to the community. This measures patterns, physical activity levels and physical activity status calculations using scoring on the GPAQ instrument.

\subsection{Criteria for the Dependent Variable:}

1. Patterns of physical activity carried out in the work, transport and recreation domains

2. Physical activity level is measured using the GPAQ instrument in the form of total Mets / Week

3. Physical activity status is categorized into physical activity status as recommended (enough> 600 Meters / Week and done 5 days, whereas if it is less if it does not meet these criteria) 


\subsection{Criteria for the Independent Variable:}

1. A person's perception of susceptibility to COVID-19 (perceived susceptibility)

2. A person's perception of the seriousness of the severity of being exposed to COVID-19 (perceived severity)

3. Barriers that will be faced when doing physical sports activities at the time of physical distancing (perceived barriers)

4. Someone's perception of the benefits when doing sports activities (perceived benefits)

\subsection{Procedure Methodology}

The data collection technique in this study used a well-designed questionnaire designed to collect data. The first step in data collection is making an instrument in the form of a questionnaire using google forms, spreading the google form questionnaire link to all the people of the special area of Yogyakarta via broadcast, in filling out the questionnaire respondents are asked to fill in as is without coercion to ensure that the data obtained is objective data, collect the results of questionnaires that have been filled in by the respondent. The data used in this study are in the form of answers to the statements obtained from the research subjects.

\subsection{Statistical Analysis}

Physical activity is a movement that is carried out in a planned manner as a form of muscle training and energy burning (Samsuddin, 2021). Physical activity is a behavior that is, because of its complex nature, difficult to assess under free-living conditions (Jasna, 2020). Whereas according to explaining that physical activity is a state of the body in experiencing minimal movement and energy does not require much in the process of burning in other words resting metabolic retest. Descriptive analysis was carried out to describe the characteristics of the subject in the form of gender, recent educational status, physical activity status and work status. Nominal and ordinal data were analyzed by calculating proportions while continuous data were calculated by means of median, mean, standard deviation. Data forms are presented in graphs, tables or diagrams.

1. Physical activity patterns and levels of physical activity were analyzed descriptively by calculating the average, standard deviation of physical activity in each domain

2. The normality test for selecting different types of tests uses the Komogorov Smirnov test

3. analysis of different tests to see the level of physical activity in different constructs of health belief mode (perceived susceptibility, perceived severity, perceived benefits, perceived barriers)

4. the correlation test for the effect of two variables between the adequacy of physical activity status and the construct of the health belief model (perceived susceptibility, perceived severity, perceived benefits, perceived barriers).

\section{Results and Discussion}

\subsection{Results}

\section{a. Description of Research Sulbjects}

Socio-demographic characteristics of 390 respondents include gender, latest education, physical activity status, work status and smoking status in the form of a description showing the characteristics of the sample used in the study are as follows: 


\section{Gender}

Of the 390 respondents, 196 or $50 \%$ were male and 194 or $50 \%$ of the respondents were female. The relatively balanced number of respondents' comparisons shows that there are more male respondents than female respondents.

2. Age Group

The comprehensive distribution of respondents covers various ages and the age groups of respondents are divided into 3, among others, adolescents, adults and the elderly, while a total of 127 respondents in adolescence are 127, in the adult category there are 136 respondents and 127 in the elderly category.

3. Educational Status

Of the 390 respondents, 9 people or $2 \%$ have primary school education (primary) 293 or $75 \%$ junior high school or high school (secondary) and 88 people or $23 \%$ tertiary education.

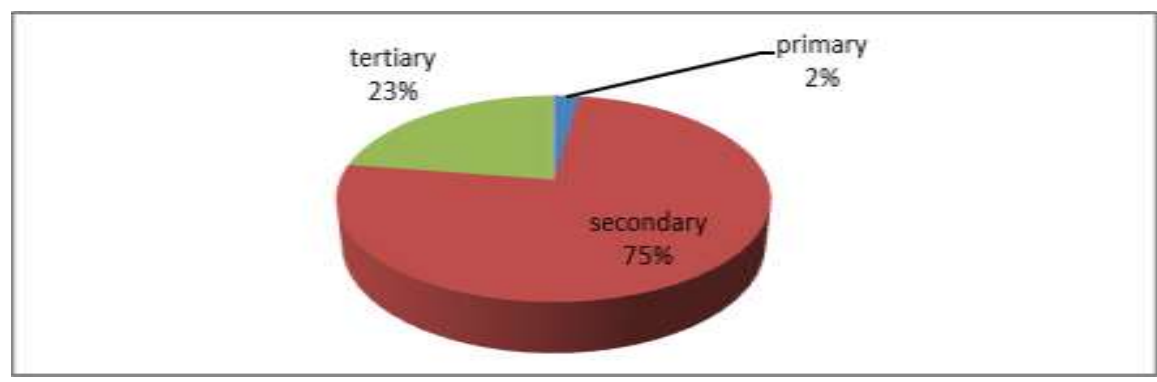

Figure 1. Educational Status

4. Working Status

Of the 390 respondents in the Special Region of Yogyakarta, 89 work as employees, 81 students, 33 work as civil servants, 13 professionals, 31 people do not work, and 143 people work as entrepreneurs.

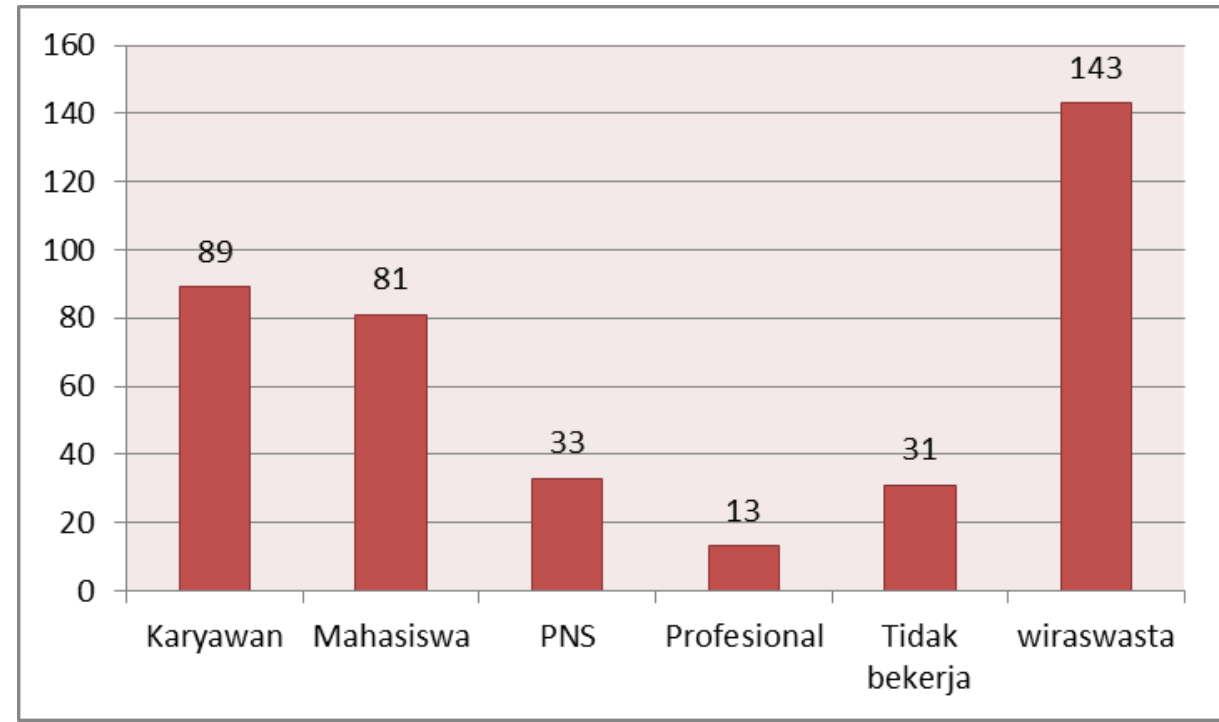

Figure 2. Working Status 


\section{b. Description of Physical Activity Data}

1. Physical Activity Patterns

Table 1. Physical Activity Patterns

\begin{tabular}{|l|l|l|l|l|l|l|}
\hline Criteria & N & Range & Min & Max & Mean & $\begin{array}{l}\text { Std. } \\
\text { deviation }\end{array}$ \\
\hline Work & 390 & 4800 & 0 & 4800 & 521.28 & 627,911 \\
\hline Transport & 390 & 1680 & 0 & 1680 & 233.54 & 293,570 \\
\hline Recreation & 390 & 6480 & 0 & 6480 & 868.37 & 996,170 \\
\hline
\end{tabular}

2. Physical Activity Level

At the level of physical activity of the DIY community can be seen in the table. From the calculation of the total physical activity level of 390 respondents and measured using the GPAQ questionnaire, it shows a minimum value of 0 and a maximum of 6480 with an average of 4153.33 in all domains. The average DIY community in the work domain has an average physical activity level of 521.28 mets / week with a std deviation of 627,911 having a minimum value of 0 and a maximum value of 4800 . In the transport domain there is an average of 233.54 mets / week with a std deviation of 293,570 the minimum value is 0 and has a maximum value of 1680. whereas in the recreation domain there is an average of 868.37 mets / week with a std deviation of 996,170 with a minimum value of 0 and a maximum value of 6480 .

3. Physical Activity Status

From the data of respondents from the DIY community, there were 390 respondents as many as 115 had a lack of physical activity status and 275 people had a sufficient level of physical activity.

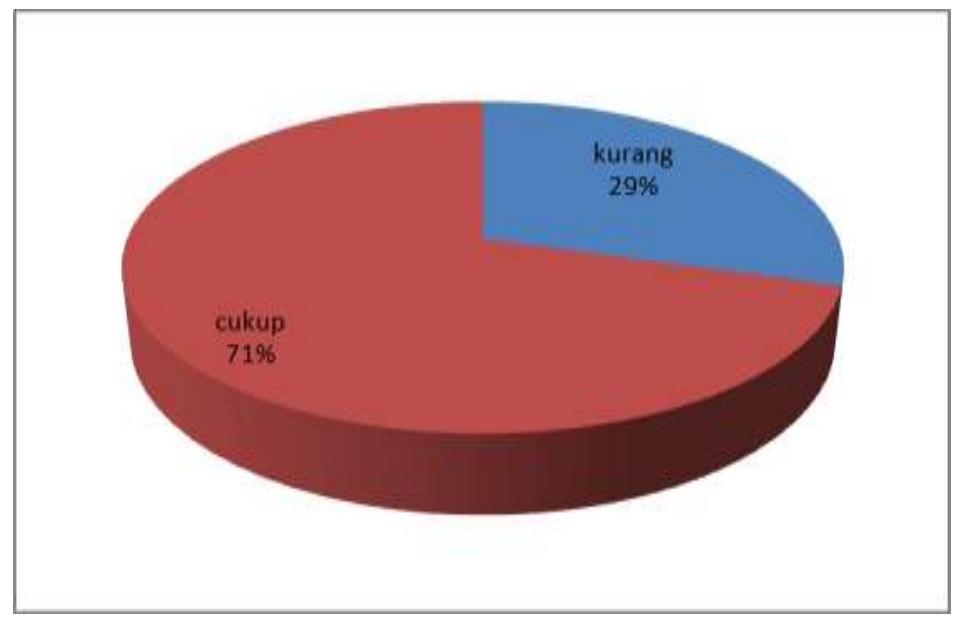

Figure 3. Physhical Activity Status 
Table 2. Test Different Levels of Physical Activity

\begin{tabular}{|c|c|c|c|c|c|c|c|}
\hline \multirow[t]{2}{*}{ Construct } & \multicolumn{6}{|c|}{ Response } & \multirow[b]{2}{*}{ TOTAL } \\
\hline & & $\mathbf{1}$ & 2 & 3 & 4 & 5 & \\
\hline \multirow{4}{*}{$\begin{array}{l}\text { Perceived } \\
\text { susceptibility }\end{array}$} & Mean & 995.37 & 1250.93 & 1924.35 & 2444.00 & 3400.00 & \\
\hline & $\begin{array}{l}\text { Std. } \\
\text { deviation }\end{array}$ & 830,5777 & 997,075 & 1181,488 & 1766,530 & 1997,699 & \\
\hline & Normality & 0.000 & 0.000 & 0.159 & 0.000 & 0.083 & \\
\hline & $\mathrm{N}$ & 121 & 97 & 102 & 45 & 25 & 390 \\
\hline \multirow{4}{*}{$\begin{array}{l}\text { Perceived } \\
\text { severity }\end{array}$} & Mean & 1110.51 & 1554.94 & 1992.62 & 3056.57 & 2984.62 & \\
\hline & $\begin{array}{l}\text { Std. } \\
\text { deviation }\end{array}$ & 937,800 & 1035,456 & 1345,615 & 2000,144 & 2158,567 & \\
\hline & Normality & 0.000 & 0.023 & 0.000 & 0.003 & 0.200 & \\
\hline & $\mathrm{N}$ & 177 & 87 & 78 & 35 & 13 & 390 \\
\hline \multirow{4}{*}{$\begin{array}{l}\text { Perceived } \\
\text { banefit }\end{array}$} & Mean & 341.46 & 684.29 & 1328.13 & 1789.07 & 2238.50 & \\
\hline & $\begin{array}{l}\text { Std. } \\
\text { deviation }\end{array}$ & 365,770 & 581,143 & 585,862 & 971,682 & 1677,703 & \\
\hline & Normality & 0.000 & 0.000 & 0.200 & 0.002 & 0.001 & \\
\hline & $\mathrm{N}$ & 41 & 42 & 64 & 86 & 157 & 390 \\
\hline \multirow{4}{*}{$\begin{array}{l}\text { Perceived } \\
\text { barriers }\end{array}$} & Mean & 2067.37 & 1656.87 & 1243.13 & 569.05 & 600.00 & \\
\hline & $\begin{array}{l}\text { Std. } \\
\text { deviation }\end{array}$ & $\begin{array}{l}1528,75 \\
0\end{array}$ & 1124,774 & 1045,068 & 507,547 & 797,547 & \\
\hline & Normality & 0.000 & 0.001 & 0.000 & 0.000 & 0.012 & \\
\hline & $\mathrm{N}$ & 185 & 83 & 64 & 42 & 16 & 390 \\
\hline
\end{tabular}

Based on the table above, there are the results of the normality test using Kolmogorov showing that the data is not normally distributed, so the next step will be a non-parametric statistical test using kruskall wallis to find out whether there are differences in the health belief model construct which includes perceived susceptibility, perceived severity, perceived benefits, and perceived barriers. 
1. Different Test of Physical Activity Levels Based on Perceived Susceptibility Based on the non-parametric statistical test output of the kruskall wallis test, it is known that the Sig value is 0.000 ( $\mathrm{P}<0.05$ ), thus it can be concluded that $\mathrm{H} 0$ shows that there is a difference in the level of physical activity between the treatment of people and respondents with different perceived susceptibility, $\mathrm{X} 2(4)=(88.651), \mathrm{P}=0.000$ which means there is a real or significant difference in the level of physical activity with the perceived susceptibility treatment. So it can be concluded that respondents with a belief about their vulnerability to be exposed to COVID-19 (perceived susceptibily) are higher, so they have a high level of physical activity as well.

2. Different Test of Physical Activity Levels Based on Perceived Severity Based on the output of the non-parametric statistical test of the Kruskall Wallis test, it is known that the Sig value is 0.000 ( $\mathrm{P}<0.05)$, thus it can be concluded that $\mathrm{H} 0$ shows that there is a difference in the level of physical activity between the treatment of people and respondents with different perceived susceptibility, $\mathrm{X} 2(4)=(68.246), \mathrm{P}=0.000$ which means there is a real or significant difference in the level of physical activity with the perceived severity treatment. So it can be concluded that respondents with a belief about the bad effects if they are exposed to COVID-19 (perceived secerity) are higher then they have a high level of physical activity too, with (mean rank 273.19)

3. Different Test of Physical Activity Levels Based on Perceived Benefit Based on the output of the non-parametric statistical test of the Kruskall Wallis test, it is known that the Sig value is 0.000 ( $\mathrm{P}<0.05)$. 125,854), $\mathrm{P}=$ 0.000 , which means that there is a significant or significant difference in the level of physical activity with the perceived benefit treatment. So it can be concluded that respondents who believe in the benefits of sports activities (perceived benefits) as self-protection from exposure to COVID-19 are higher (mean rank 262.67) will have a high level of physical activity as well.

4. Different Test for Physical Activity Levels Based on Perceived Barriers

Based on the output of the non-parametric statistical test of the Kruskall Wallis test, it is known that the Sig value is 0.000 ( $\mathrm{P}<0.05)$, thus it can be concluded that $\mathrm{H} 0$ shows that there is a difference in the level of physical activity between the treatment of people and respondents with different perceived barriers, $\mathrm{X} 2(4)=(83.192), \mathrm{P}=0.000$ which means that there is a significant or significant difference in the level of physical activity with the treatment of perceived barriers. So it can be concluded that respondents who do not have confidence in the obstacles that will be accepted when doing sports activities during the pandemic have a better level of physical activity (Mean Rank $=234.99$ METS) compared to respondents who have confidence in the obstacles that will be accepted when doing sports activities during a pandemic with (Mean rank $=86$.

Table 3. Correlation Test between Physical Activity Levels (GPAQ) and Perceived Susceptibility

\section{SUCEPTIBILITY}

\begin{tabular}{|l|l|l|l|l|l|l|l|}
\hline criteria & & Strongly & Disagree & neutral & Strongly & agree & total \\
\hline
\end{tabular}




\begin{tabular}{|c|l|l|l|l|l|l|l|}
\hline & & disagree & & & agree & & \\
\hline \multirow{3}{*}{$\begin{array}{c}\text { Physical } \\
\text { activity status }\end{array}$} & Less & 55 & 40 & 17 & 3 & 0 & 115 \\
\cline { 2 - 8 } & Percent\% & $47 \%$ & $34 \%$ & $14 \%$ & $2 \%$ & $0 \%$ & $29.5 \%$ \\
\cline { 2 - 8 } & Enough & 66 & 57 & 85 & 42 & 25 & 275 \\
\cline { 2 - 8 } & Percent\% & $24 \%$ & $20 \%$ & $31 \%$ & $15 \%$ & $10 \%$ & $70.5 \%$ \\
\hline \multirow{3}{*}{ Total and percent\% } & 121 & 97 & 102 & 45 & 25 & 390 \\
\cline { 2 - 8 } & $46 \%$ & $39 \%$ & $11 \%$ & $4 \%$ & $0 \%$ & $100 \%$ \\
\hline
\end{tabular}

Chi-square test was conducted to examine the relationship between physical activity status and perceived susceptibility. The relationship between these variables is significant $\mathrm{X} 2(\mathrm{df} 4, \mathrm{~N} 390)=$ Value $51.067 \mathrm{p}=000$. So it can be concluded that people who feel that they are more vulnerable to exposure to COVID-19 will have the awareness to carry out physical activity in accordance with health recommendations compared to people who feel less about the vulnerability of exposure to COVID-19.

Table 4. Correlation Test between Physical Activity Levels (GPAQ) and Perceived Severity

\begin{tabular}{|c|l|l|l|l|l|l|l|}
\hline \multicolumn{2}{|c|}{ SEVERITY } \\
\hline \multirow{2}{*}{$\begin{array}{l}\text { Strongly } \\
\text { criteria }\end{array}$} & Disagree & neutral & $\begin{array}{l}\text { Strongly } \\
\text { agree }\end{array}$ & agree & total \\
\hline \multirow{3}{*}{$\begin{array}{c}\text { Physical } \\
\text { activity status }\end{array}$} & Less & 78 & 24 & 12 & 0 & 1 & 115 \\
\cline { 2 - 9 } & Percent\% & $67.8 \%$ & $20.8 \%$ & $10.4 \%$ & $0 \%$ & $0.1 \%$ & $29.5 \%$ \\
\cline { 2 - 9 } & Enough & 99 & 63 & 66 & 35 & 12 & 275 \\
\cline { 2 - 9 } & Percent\% & $36 \%$ & $22.9 \%$ & $24 \%$ & $12 \%$ & $4.3 \%$ & $70.5 \%$ \\
\hline \multirow{2}{*}{ Total and percent\% } & 177 & 87 & 78 & 35 & 13 & 390 \\
\cline { 2 - 8 } & $45.3 \%$ & $22.3 \%$ & $20 \%$ & $9 \%$ & $3.4 \%$ & $100 \%$ \\
\hline
\end{tabular}

Chi-square test was conducted to examine the relationship between physical activity status and perceived severity. The relationship between these variables is significant $\mathrm{X} 2$ $($ df $4, \mathrm{~N} 390)=$ Value 43,316 $\mathrm{p}=000$. From the data presentation, it can be concluded that people who have confidence in severity when exposed to COVID-19 (perceived severity) will have awareness to do physical activity in accordance with health recommendations compared to people who were less likely to feel the severity of exposure to COVID-19. 
Table 5. Correlation Test between Physical Activity Level (GPAQ) and Perceived Benefit

\begin{tabular}{|c|l|l|l|l|l|l|l|}
\hline \multicolumn{2}{|c|}{ BENEFIT } \\
\hline \multirow{2}{*}{ criteria } & $\begin{array}{l}\text { Strongly } \\
\text { disagree }\end{array}$ & Disagree & neutral & $\begin{array}{l}\text { Strongly } \\
\text { agree }\end{array}$ & agree & total \\
\hline \multirow{3}{*}{$\begin{array}{c}\text { Physical } \\
\text { activity status }\end{array}$} & Less & 34 & 28 & 13 & 9 & 31 & 115 \\
\cline { 2 - 9 } & Percent\% & $29.5 \%$ & $24.3 \%$ & $11.3 \%$ & $8 \%$ & $26.9 \%$ & $29.5 \%$ \\
\cline { 2 - 9 } & Enough & 7 & 14 & 51 & 77 & 126 & 275 \\
\cline { 2 - 9 } & Percent\% & $3 \%$ & $5.9 \%$ & $2.5 \%$ & $5 \%$ & $2.5 \%$ & $70.5 \%$ \\
\hline \multirow{3}{*}{ Total and percent\% } & 41 & 42 & 64 & 86 & 157 & 390 \\
\cline { 2 - 8 } & $10.5 \%$ & $10.7 \%$ & $16.4 \%$ & $22.1 \%$ & $40.3 \%$ & $100 \%$ \\
\hline
\end{tabular}

Chi-square test was conducted to examine the relationship between physical activity status and perceived severity. The relationship between these variables is significant X2 $(\mathrm{df} 4, \mathrm{~N} 390)=$ Value $108,959 \mathrm{p}=0.000$. From the data presentation, it can be concluded that people who believe in the benefits of physical activity (perceived benefits) to reduce the risk of being infected with COVID-19 will have the awareness to do physical activity in accordance with health recommendations compared to people who do not understand the benefits of activity. Physical activity to reduce exposure to COVID-19.

Table 6. Correlation Test between Physical Activity Levels (GPAQ) and Perceived Barriers

\begin{tabular}{|c|c|c|c|c|c|c|c|}
\hline & & & BARRIF & & & & \\
\hline & eria & & Disagre & neutra & Strongl & agre & Total \\
\hline & Less & 34 & 16 & 22 & 33 & 10 & 115 \\
\hline $\begin{array}{c}\text { Physica } \\
\text { l }\end{array}$ & $\begin{array}{l}\text { Percent } \\
\%\end{array}$ & $29.5 \%$ & $13.9 \%$ & $20 \%$ & $28 \%$ & $8.6 \%$ & $\begin{array}{l}29.4 \\
\%\end{array}$ \\
\hline status & Enough & 151 & 67 & 42 & 9 & 6 & 275 \\
\hline & $\begin{array}{l}\text { Percent } \\
\%\end{array}$ & $54.9 \%$ & $24.4 \%$ & $15.3 \%$ & $3.3 \%$ & $2.1 \%$ & $\begin{array}{l}70.5 \\
\%\end{array}$ \\
\hline & & 185 & 83 & 64 & 42 & 16 & 390 \\
\hline & $\begin{array}{l}1 \text { and } \\
\text { ent\% }\end{array}$ & $47.4 \%$ & $21.3 \%$ & $16.4 \%$ & $10.8 \%$ & $4.1 \%$ & $100 \%$ \\
\hline
\end{tabular}


Chi-square test was conducted to examine the relationship between physical activity status and perceived barriers. The relationship between these variables is significant X2 (df $4, \mathrm{~N} \mathrm{390)}=$ Value 72,930 $\mathrm{p}=0.000$. From the presentation of these data, it can be concluded that people who have beliefs about the perception of obstacles when doing physical activity will tend to have a lower level of physical activity compared to people who do not have a perception of servitude when doing physical activity.

\subsection{Dis cussion}

The purpose of this study was to determine the pattern, level and status of physical activity of the Yogyakarta community and its relation to the construct of the health belief model, namely perceived, susceptibility, perceived severity, perceived benefits, and perceived barriers. Analytical observational research was carried out by conducting observations without any treatment from the researcher, the research sample was taken using conventional sampling methods by means of the public filling out a questionnaire on an online form that has been distributed via digital platforms.

Overall data analysis shows that the DIY community is more dominant in recreational activities or sports that are done in their spare time which are usually done independently. This may be due to restrictions on work activities and transport. Most of the DIY people are classified as sufficient physical activity. Furthermore, research also shows that people with better constructs of perceived susceptibility, perceived severity, benefits, and perceived barriers have a high level of physical activity. In addition, correlational analysis also shows a significant positive relationship between physical activity status and the construct of perceived susceptibility, perceived severity, perceived benefits and a significant negative relationship with perceived barriers.

This is also in line with Berli et al (2014)that health belief is very important in the process of forming intention or motivation to behave healthy. Strengthened byKaiser et al (2013)Regarding health belief, it is very effective to improve physical activity behavior, someone believes that the benefits of a change in changing physical activity will lead to positive results, explaining also about preventive behavior in someone who wants to take preventive measures, follow screening and control of existing diseases. So are opinionsFathian-Dastgerdi et al., (2021)that health belief can provide a useful framework for planning a health program and help improve proactive behavior in physical activity. However, these behavioral changes do not affect the intensity when doing research sports activities conducted bySetiyorini \& Farida Tantiani (2020) in a fitness center in Malang.

In line with research conducted by Ashadi et al (2020) At the time of the COVID-19 pandemic, changes in the behavior of sports activity patterns were of significant value including the habit of doing sports activities, as well as the types of activities, research conducted on sports and non-sports students during the COVID-19 pandemic $(p<0.05)$ that means health belief the model greatly influences a person to make changes to physical activity.

These results indicate that the assumptions of the Health Belief Model theory, where a person with a low Health Belief Model status has a tendency to engage in health behavior or in this context is physical sports activity. Conversely, if the Health Belief status is high, then a person will not do physical activity. This COVID-19 pandemic forces us to adapt while looking for a way out to reduce the level of spread by living more actively to boost the immune system. While adapting activities outside the home with the correct health protocol and getting used to continuing activities, someone at a productive age can do activities that can reduce the level of boredom and increase pleasure. 


\section{Conclusion}

Based on the results of data analysis and hypothesis testing as a whole, the following conclusions can be drawn:

1. The physical activity patterns of the DIY community in the new normal era of the COVID-19 pandemic were mostly carried out in the recreation domain, followed by work and transport domains.

2. There is a significant difference in the level of physical activity in people with different health belief models. People with a good health belief model construct status have a higher level of physical activity than people with a low health belief model construct status.

3. There is a relationship between physical activity status and different health belief models. People who have a health belief model construct status that is getting better have a significant relationship with moderate physical activity status and there is a result value $(\mathrm{P}<0.00)$ and a correlation value of 0.89 , which means that there is a very strong relationship between the construct of the health belief model and the adequacy of physical activity status at DIY community.

\section{References}

Ashadi, K., Andriana, L. M., \& Pramono, A. (2020). Pola Aktivitas Olahraga Sebelum dan Selama Masa Pandemi Covid-19 pada Mahasiswa Fakultas Olahraga dan Fakultas Non-Olahraga. 6(3), 713-728.

Berli, C., Loretini, P., Radtke, T., Hornung, R., \& Scholz, U. (2014). Predicting Physical Activity in Adolescents: The Role of Compensatory Health Beliefs within the Health Action Process Approach. Psychology and Health, 29(4), 458-474. https://doi.org/10.1080/08870446.2013.865028

Fathian-Dastgerdi, Z., khoshgoftar, M., Tavakoli, B., \& Jaleh, M. (2021). Factors Associated with Preventive Behaviors of COVID-19 among Adolescents: Applying the Health Belief Model. Research in Social and Administrative Pharmacy. https://oi.org/10.1016/j.sapharm.2021.01.014

Fauziyati, A. (2017). Global Challenge of Early Detection and Management of Chronic Kidney Disease. Jurnal Kedokteran dan Kesehatan Indonesia. https://doi.org/10.20885/jkki. vol8. iss1.art1

Jasna, P., Milos, P., and Ružena, C. (2020). Comparative Analysis of the Physical Activity, Nutrition and Health Behaviour in Physical Education Students: Gender Differences. Britain International of Linguistics, Arts andEducation (BIoLAE) Journal Vol. 2 (2): 676-687.

Kaiser, B., Razurel, C., \& Jeannot, E. (2013). Impact of Health Beliefs, Social Support and Self-Efficacy on Physical Activity and Dietary Habits during the Post-Partum Period after Gestational Diabetes Mellitus: Study Protocol. BMC Pregnancy and Childbirth, 13. https://doi.org/10.1186/1471-2393-13-133.

Morawska, L., \& Cao, J. (2020). Airborne transmission of SARS-CoV-2: The World should Face the Reality. In Environment International. https://doi.org/10.1016/j.envint.2020.105730

Samsudin, Maksum, A., and Priambodo, A. (2021). The Effect of Foster Care and SelfEfficacy on the Physical Activities of Elementary School Students. Budapest 
International Research and Critics in Linguistics and Education (BirLE) Journal Vol 4 (1): 114-124.

Setiyorini, A., \& Farida Tantiani, F. (2020). Hubungan Faktor-Faktor Health Belief Model dengan Intensitas Berolahraga di sebuah Fitness Center Kota Malang. In Seminar $\begin{array}{lllll}\text { Nasional } & \text { Psikologi } & \text { UM } & \end{array}$ http://conference.um.ac.id/index.php/psi/article/view/37

WHO Tool for Behavioural Insights on COVID-19. (2020). https://www.euro.who.int/en/health-topics/health-emergencies/coronavirus-covid19/technical-guidance/who-tool-for-behavioural-insights-on-covid-19

Zendrato, W. (2020). Gerakan Mencegah Daripada Mengobati terhadap Pandemi Covid19. Jurnal Education and Development. 